\title{
Machining Parameter Optimization of Al/SiC/Gr Hybrid Metal Matrix Composites using ANOVA and Grey Relational Analysis
}

Mallichetty Elango

Assistant Professor(Selection Grade) School of Mechanical Engineering and Building Science Vellore Institute of Technology, Chennai

\section{Krishnamoorthy Annamalai \\ Professor \\ School of Mechanical Engineering and Building Science \\ Vellore Institute of Technology, Chennai}

This research work focuses on the impact of graphite addition to the Al/SiC hybrid metal matrix composites manufactured by stir casting process. Three specimens were prepared with Al6061 alloy $+5 \mathrm{wt} . \% \mathrm{SiC}$ and varying weight percent of graphite. Al6061 matrix material is suitable for machining and welding applications commonly used in construction of aircraft wings and fuselages. Machining of composite materials is often required to meet dimensional tolerances, surface roughness and to create holes. A layered SiC/Gr composite material is used in gas turbine combustor can. Machining of Al/SiC/Gr hybrid composite was done in Esteem ETM 356 lathe using tungsten carbide insert. Optimization of three machining parameters cutting speed, feed rate and depth of cut, was done using four levels. From ANOVA results feed rate (35.83\%) is the important factor influencing surface roughness. Grey Relational analysis was done for simultaneous improvement of Material Removal Rate and surface roughness.

Keywords: Hybrid metal matrix composites, Al6061, SiC, Graphite, Surface roughness, ANOVA, GRA.

\section{INTRODUCTION}

Aluminium alloy based composites are widely used in aerospace and automotive industries. Aluminium and its alloys are most economical and attractive due to light weight, fabricability, mechanical properties, and corrosion resistance [1]. Most of the research works on metal matrix composites are done on the following three metals, Aluminium, Magnesium and Titanium.

To improve the properties of MMCs two or more reinforcements are added to the matrix, this leads to the formation of a new hybrid composite. MMCs are composed of a metal matrix and a reinforcement, or filler material. The main matrix materials for MMCs are aluminium and its alloys. To a lesser extent, magnesium, titanium, copper, zinc or lead matrix is also used. MMCs with continuous fiber reinforcements have better mechanical properties than MMCs with discontinuous reinforcements [2].

Commonly used second reinforcement in hybrid composites are $\mathrm{Gr}, \mathrm{Al}_{2} \mathrm{O}_{3}, \mathrm{~B}_{4} \mathrm{C}$ of which $\mathrm{Al} / \mathrm{SiC} / \mathrm{Gr}$ is an important hybrid composite, because $\mathrm{SiC}$ is harder than Tungsten carbide (WC) and Graphite particles provide high resistance to wear in the hybrid composite $[3,4]$. $\mathrm{SiC}$ is much easier to synthesize than diamond and can be produced readily in large quantities in a crude form such as powder. SiC-particulate-reinforced aluminium composites have found many applications such as brake

Received: April 2019, Accepted: August 2019

Correspondence to: M. Elango, School of Mechanical

Engineering and Building Science, Vellore Institute of

Technology, Chennai, India

E-mail: elango.m@vit.ac.in

doi:10.5937/fmet2001173M

(C) Faculty of Mechanical Engineering, Belgrade. All rights reserved discs, bicycle frames, aerospace and automotive industry. Graphite particles present in $\mathrm{Al} / \mathrm{SiC} / \mathrm{Gr}$ composites are solid lubricant and act as a chip breaker, due to this discontinuous chips are produced and tool wear is reduced [5].

Machining process in composite materials cannot be eliminated completely, due to the size and dimensional requirements. A number of researchers have conducted experiments in machining Aluminium metal matrix composites using various machining process. CNC lathe $\&$ medium duty lathe under dry turning conditions and machining parameters like cutting speed, feed rate, depth of cut were considered by various researchers for optimization, with surface roughness as their desired target. Tool life is usually shorter due to the abrasive nature of the composite. Traditional high speed steel tool is not suitable for machining MMCs due to rapid growth of tool wear. PCD tools are used for machining carbon-reinforced composites due to high wear resistance $[6,7]$.

Suresh [8] found that higher reinforcement content of Si-Gr promotes brittleness, because of brittleness built-up edge formation disappears. Built-up edge formation leads to tool failures when tools with carbide inserts are reduced, decreses the life of cutting tool. Muthukrishnan [9] studied about the surface roughness of $\mathrm{Al}-\mathrm{SiC}(20 \mathrm{p})$ by turning using coarse grade PCD insert under different cutting conditions and tested their experimental data with ANOVA and ANN techniques.

Basavarajappa [10] found that graphite in Al 2219 /15 SiCp composite particle increases the surface roughness due to smearing and removal of softer and amorphous graphite particles on the surface of the specimen. Suhasini [11] reviewed machining of MMCs: 
slower speeds, higher feeds and depth of cuts contribute to the formation of Built up edge (BUE). Discontinuous chips result in better surface roughness values. Increased reinforced percentages and sizes resulted in increased surface roughness. Cutting forces were much larger for Tungsten carbide tools than PCD tools due to the formation of BUE.

Tian [12] found that surface roughness has a tendency to increase first and then decrease with the increase in cutting speed. For cutting speeds less than 150 $\mathrm{m} / \mathrm{min}$, the BUE tends to form and this may lead to increase in surface roughness, whereas for cutting speeds higher than $200 \mathrm{~m} / \mathrm{min}$ the softening of the work piece material due to increased temperature results in lower temperature.

Toth-Laufer and Richard Horvath [13] investigated surface roughness prediction of fine turning using central composite experimental design. Average surface Roughness $R_{a}$ and $R_{z}$ were considered in this study for developing a predictive fuzzy-based model. Lazarevic [3] investigated the influence of cutting speed, feed rate, depth of cut and tool nose radius on main cutting force using L27 Taguchi's orthogonal array. Abdullah [14] investigated the effect of surface roughness on the thermolectric behaviour of friction clutches, developed axisymmetric finite element model for a single-disc clutch system.

Marichamy [15] optimized machining parameters for $\alpha-\beta$ brass manufactured by stir casting process using Taguchi method for abrasive water jet machining. Dhawan [16] developed a new ANN approach to predict drilling-induced thrust force and torque. Sivaiah [17] tested the cryogenic machining of stainless steel; from the ANOVA analysis feed rate is the most influencing process parameter on the performance characteristics.

A review of literatures indicates that the study on machining of $\mathrm{Al} / \mathrm{SiC} / \mathrm{Gr}$ hybrid composites are very limited. Machining parameter optimization with four levels and hybrid composite manufacturing by varying weight percentage of graphite is not carried out by researchers. The present study uses three specimens of $\mathrm{Al} / \mathrm{SiC} / \mathrm{Gr}$ hybrid metal matrix composites manufactured by stir casting method with varying weight percent of graphite. Sixteen experimental runs with three parameters and four levels were conducted in Esteem ETM 356 lathe machine using new tungsten carbide inserts to determine the optimum machining parameters. SEM micrographs and EDAX analysis were done to check the elemental contribution in hybrid metal matrix composites.

\section{EXPERIMENTAL PROCEDURES}

Hybrid MMCs of type (Al $6061+5 \% \mathrm{SiC}+2.5 \% \mathrm{Gr}$, $\mathrm{Al} 6061+5 \% \mathrm{SiC}+5 \% \mathrm{Gr}$ and $\mathrm{Al} 6061+5 \% \mathrm{SiC}+$ $7.5 \%$ Gr) were manufactured using stir casting method. The matrix material used was Al6061 (magnesium and silicon are principal alloying elements), has good resistance to corrosion. The chemical composition of Al6061 alloy is Si 0.4-0.8\%, $\mathrm{Mg} 0.8-1.2 \%$, Fe 0.7, Cu 0.15-0.4\%, Mn 0.15\%, Cr $0.04-0.35 \%$, Zn 0.25\%, Ti 0.15\%, Al-balance. Al6061 alloy is widely used in aircraft, defence, automobiles and marine applications. The average particle size of
$\mathrm{SiC}$ and $\mathrm{Gr}$ used was $40 \mu \mathrm{m}$. The $\mathrm{SiC}$ and $\mathrm{Gr}$ particles were kept in powder particle furnace at $400^{\circ} \mathrm{C}$ for 3 hours. Al6061 alloy was heated to $800^{\circ} \mathrm{C}$ in a graphite crucible and the melt was degassed and cleaned to remove impurities, increase wettability and to reduce porosity. $\mathrm{SiC}$ and $\mathrm{Gr}$ particles were added simultaneously and mixed homogeneously in A16061 alloy matrix at a stirring speed of $400 \mathrm{rpm}$. Pouring of molten slurry into the mould is done through the bottom using a remote control switch.

\subsection{FESEM Analysis}

The microstructure of work material $(\mathrm{Al}+5 \% \mathrm{SiC}+2.5$ $\% \mathrm{Gr}$ ) is shown in Figure 1. The reinforcement ( $\mathrm{SiC}$ and Gr) particles were evenly distributed within the matrix alloy; it shows that stir casting method can be used for the manufacturing of $\mathrm{Al} / \mathrm{SiC} / \mathrm{Gr}$ composites with improved properties and reduced particle clusters. The graphite takes the form of flakes and the $\mathrm{Al}$ particles appear in round and cylindrical shapes, $\mathrm{SiC}$ particles have an ellipsoidal shape. The SiC particles appear like cubes; Gr particles are seen as dark regions or as pores formed during polishing of surface. The micrographs indicate perfect bonding between different components of $\mathrm{Al}$ composites and absence of cracks. The result of the micro structural analysis revealed a non-uniform distribution of graphite particles takes place at all the three specimens.

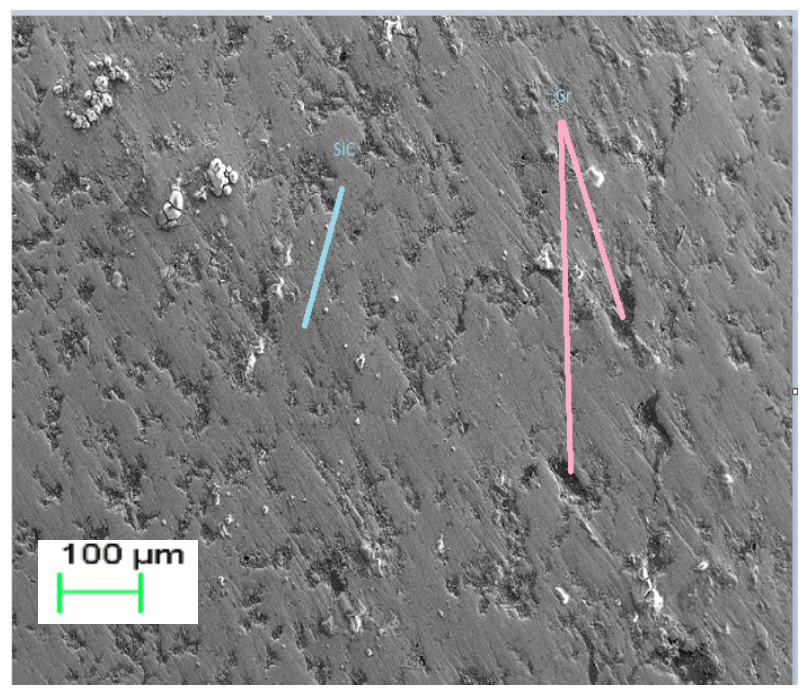

Figure 1. Al + 5\% SiC + $2.5 \%$ Gr SEM micrograph

The hardness values of aluminium hybrid composites with $5 \% \mathrm{SiC}$ and $2.5 \% \mathrm{Gr}, 5 \% \mathrm{Gr}, 7.5 \% \mathrm{Gr}$ are $83 \mathrm{VHN}, 72 \mathrm{VHN}$ and $54 \mathrm{VHN}$ respectively. Hardness of $\mathrm{Al} / \mathrm{SiC} / \mathrm{Gr}$ hybrid composite decreases with increase in weight $\%$ of graphite content.

\subsection{EDAX Analysis}

EDAX (Energy Dispersive X-ray analysis) is done for $\mathrm{Al} / \mathrm{SiC} / \mathrm{Gr}$ specimen. EDAX results in Figure 2 show the presence of Aluminium in major peak \& presence of other alloys in minor peaks. $\mathrm{Si}, \mathrm{C}, \mathrm{Mg}$ and other alloys present in Al6061 is also seen. The elemental characterization reveals perfection in the process of fabrication by the method of stir casting. 


\begin{tabular}{|c|c|c|}
\hline Element & Weight\% & Atomic\% \\
\hline $\mathrm{O} \mathrm{K}$ & 10.04 & 15.94 \\
\hline $\mathrm{Mg} \mathrm{K}$ & 1.19 & 1.24 \\
\hline $\mathrm{Al} \mathrm{K}$ & 83.86 & 78.90 \\
\hline $\mathrm{Si} \mathrm{K}$ & 3.73 & 3.38 \\
\hline $\mathrm{Ca} \mathrm{K}$ & 0.15 & 0.10 \\
\hline $\mathrm{Fe} \mathrm{K}$ & 0.71 & 0.32 \\
\hline $\mathrm{Cu} \mathrm{K}$ & 0.31 & 0.13 \\
\hline
\end{tabular}

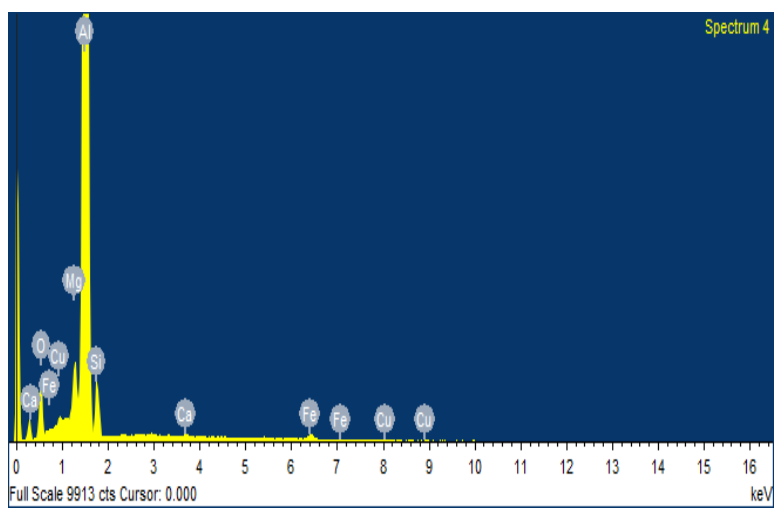

Figure 2. EDAX analysis of specimen

Graphite has been completely absorbed due to the phenomenon of diffraction based on the focus of the electron beam. Low intensity oxygen peak was observed due to oxide formation.

Experimental parameters are given in table 1. Esteem ETM 356 lathe machine was used to carry out the experiments. The TNMG 160408 tungsten carbide inserts were used to turn the $50 \mathrm{~mm}$ diameter, $300 \mathrm{~mm}$ length specimen. The $\mathrm{Al} / \mathrm{SiC} / \mathrm{Gr}$ hybrid specimens are machined at four different cutting speeds, feed rate and depth of cut. The average surface finish $\left(\mathrm{R}_{\mathrm{a}}\right)$ was measured in the machined surface using Mitutoyo Surf test SJ-201 with a cut off and traverse length of 0.8 and $5 \mathrm{~mm}$, respectively.

Table 1. Experimental conditions

\begin{tabular}{|l|l|}
\hline Machine & Esteem ETM 356 lathe machine \\
\hline Tool insert & $\begin{array}{l}\text { Tungsten carbide tool insert TNMG } \\
160408\end{array}$ \\
\hline Tool holder & ETJNL $-2020 \mathrm{~K} 16$ \\
\hline $\begin{array}{l}\text { Machining } \\
\text { parameters }\end{array}$ & $\begin{array}{l}\text { Cutting speed }: 26,40,60 \text { and } 92 \\
\mathrm{~m} / \mathrm{min}\end{array}$ \\
& $\begin{array}{l}\text { Feed rate }: 0.256,0.373,0.466 \text { and } \\
0.561 \mathrm{~mm} / \mathrm{rev} \\
\text { Depth of Cut }: 0.2,0.4,0.6 \text { and } 0.8 \\
\text { mm }\end{array}$ \\
\hline $\begin{array}{l}\text { Surface Roughness } \\
\text { equipment }\end{array}$ & Mitutoyo Surf test -201 \\
\hline Coolant & Dry machining \\
\hline
\end{tabular}

\section{EXPERIMENTAL DATA}

The experimental data consists of four replicates. The experiments were designed using Taguchi's $\mathrm{L}_{16}$ orthogonal array with 16 experiments [18]. Machining parameters and surface roughness measured for various experiments are shown in table 2 .

From table 2, it is observed that at cutting speed of $26 \mathrm{~m} / \mathrm{min}$, feed rate $0.256 \mathrm{~mm} / \mathrm{rev}$ and $0.2 \mathrm{~mm}$ surface roughness is low and at high cutting speed $92 \mathrm{~m} / \mathrm{min}$, feed rate $0.561 \mathrm{~mm} / \mathrm{rev}$ and $0.2 \mathrm{~mm}$ depth of cut MRR is high.
Table 2 Experimental results using $L_{16}$ orthogonal array

\begin{tabular}{|c|c|c|c|c|c|c|}
\hline 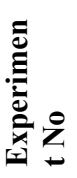 & 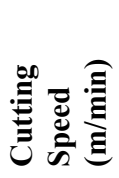 & 䒿 & 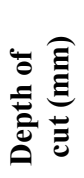 & $\begin{array}{l}\text { हैं } \\
\text { क्ष } \\
\text { के }\end{array}$ & 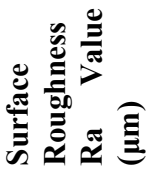 & 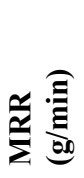 \\
\hline 1 & 26 & 0.256 & 0.2 & 1 & 6.19 & 1.33 \\
\hline 2 & 26 & 0.373 & 0.4 & 2 & 10.49 & 3.87 \\
\hline 3 & 26 & 0.466 & 0.6 & 3 & 12.05 & 7.24 \\
\hline 4 & 26 & 0.561 & 0.8 & 2 & 11.02 & 11.63 \\
\hline 5 & 40 & 0.256 & 0.4 & 3 & 9.68 & 4.10 \\
\hline 6 & 40 & 0.373 & 0.2 & 3 & 9.25 & 2.99 \\
\hline 7 & 40 & 0.466 & 0.8 & 1 & 9.66 & 14.93 \\
\hline 8 & 40 & 0.561 & 0.6 & 2 & 13.36 & 13.48 \\
\hline 9 & 60 & 0.256 & 0.6 & 2 & 13.82 & 9.28 \\
\hline 10 & 60 & 0.373 & 0.8 & 3 & 7.99 & 18.04 \\
\hline 11 & 60 & 0.466 & 0.2 & 2 & 12.27 & 5.63 \\
\hline 12 & 60 & 0.561 & 0.4 & 1 & 14.07 & 13.56 \\
\hline 13 & 92 & 0.256 & 0.8 & 2 & 6.61 & 18.81 \\
\hline 14 & 92 & 0.373 & 0.6 & 1 & 6.74 & 20.55 \\
\hline 15 & 92 & 0.466 & 0.4 & 1 & 7.41 & 17.12 \\
\hline 16 & 92 & 0.561 & 0.2 & 3 & 11.76 & 10.31 \\
\hline
\end{tabular}

\subsection{Analysis of variance}

The ANOVA analysis was done to statistically analyze the relative significance of the machining parameters such as cutting speed (A), feed rate (B), and depth of cut (C) on the response variable (surface roughness $R_{a}$ ). The model has been developed for $95 \%$ level of confidence. Based on the experimental results of the responses, a first order model has been developed for surface roughness using Minitab software.

Regression Equation

$\mathrm{Ra}=10.148-0.211$ Speed_26 +0.339 Speed_40

+1.889 Speed_60 - 2.018 Speed_92

- 1.073 Feed_0.256 - 1.531 Feed_0.373

+0.199 Feed $0.466+2.404$ Feed 0.561

- 0.281 DOC_0.2 +0.264 DOC_0.4 +1.344 DOC_0.6 -

1.328 DOC_ 0.8

Table 3 Analysis of variance of Surface Roughness

\begin{tabular}{|c|c|c|c|c|c|c|}
\hline 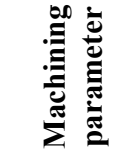 & 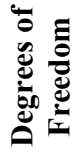 & 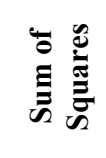 & 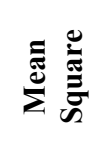 & $\frac{\stackrel{0}{\Xi}}{\frac{\Xi}{J}}$ & $\frac{\stackrel{0}{\Xi}}{\stackrel{\Xi}{\sigma}}$ & 递 \\
\hline $\begin{array}{c}\text { Cutting } \\
\text { speed }\end{array}$ & 3 & 31.21 & $\begin{array}{c}10.40 \\
3\end{array}$ & 3.02 & 0.115 & 30.01 \\
\hline Feed rate & 3 & 37.26 & $\begin{array}{c}12.42 \\
0 \\
\end{array}$ & 3.61 & 0.085 & 35.83 \\
\hline $\begin{array}{l}\text { Depth of } \\
\text { cut }\end{array}$ & 3 & 14.88 & 4.96 & 1.44 & 0.321 & 14.3 \\
\hline Error & 6 & 20.65 & 3.441 & & & 19.85 \\
\hline Total & 15 & 103.99 & & & & 100 \\
\hline
\end{tabular}

From ANOVA table 3, the cutting speed and feed rate have major influence on the roughness value, whereas depth of cut has minor effect on the surface roughness.

\subsection{Determination of optimum factor level combination}

The optimum machining parameters for conducting confirmation experiment using $\mathrm{S} / \mathrm{N}$ ratio is $\mathrm{A}_{3} \mathrm{~B}_{4} \mathrm{C}_{3} \mathrm{D}_{1}$. 
The parameter for which the line has highest inclination has greatest effect, whereas the line which is near horizontal means, the parameter has little effect on surface roughness. From Figure 3, cutting speed and feed rate has major effect on surface roughness, compared to depth of cut.

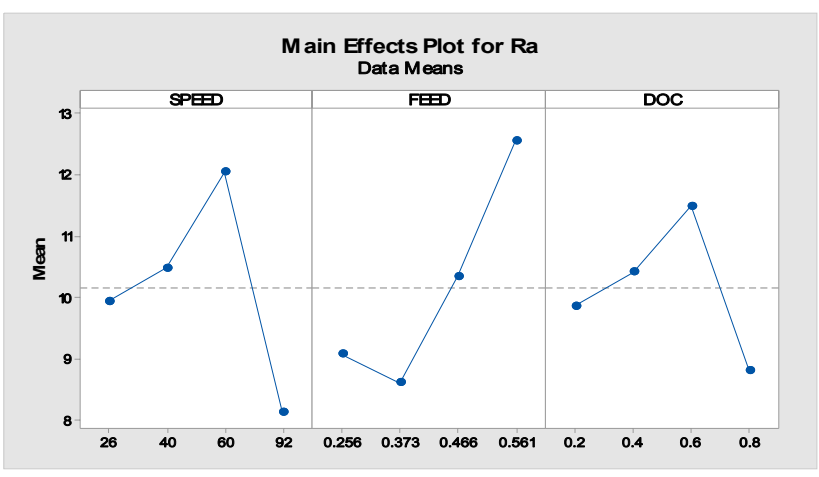

Figure 3. Main Effects plot for SN Ratio

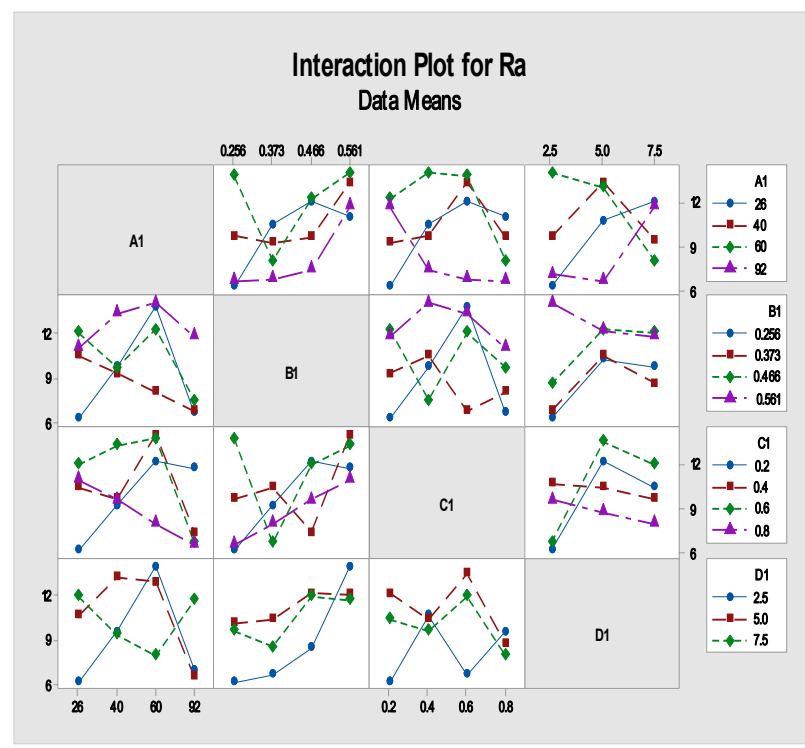

Figure 4. Interaction plot for Surface Roughness

In the interaction plot, if lines are parallel to each other there is no interaction between elements. If the lines are not parallel to each other, an interaction may be present. If we have three or more factors, interaction plot will be displayed in matrix. The greater the difference in slope between the lines, the higher the degree of interaction. From Figure 4, cutting speed of $92 \mathrm{~m} / \mathrm{min}$, with feed rate of $0.561 \mathrm{~mm} / \mathrm{rev}$ is better for getting minimum $\mathrm{R}_{\mathrm{a}}$.

Table 4. Taguchi response table for $\mathrm{S} / \mathrm{N}$ ratio

\begin{tabular}{|c|c|c|c|c|}
\hline \multirow{2}{*}{ Factors } & \multicolumn{4}{|c|}{ S/N ratio (dB) } \\
\cline { 2 - 5 } & Level 1 & Level 2 & Level 3 & Level 4 \\
\hline $\begin{array}{c}\text { Cutting speed } \\
\text { A(m/min) }\end{array}$ & -19.677 & -20.313 & -21.4 & $-17.94^{@}$ \\
\hline $\begin{array}{c}\text { Feed rate B } \\
\text { (mm/rev) }\end{array}$ & -18.691 & $-18.59^{@}$ & -20.122 & -21.993 \\
\hline $\begin{array}{c}\text { Depth of cut } \\
\text { (mm) }\end{array}$ & -19.584 & -20.123 & -20.87 & $-18.658^{(a)}$ \\
\hline $\begin{array}{c}\% \\
\text { reinforcement } \\
\text { of Graphite } \\
\text { (D) }\end{array}$ & $\begin{array}{c}18.493 \\
@\end{array}$ & -20.794 & -20.02 & - \\
\hline
\end{tabular}

(a) - Optimum results of minimum Ra
Taguchi response shown in table 4 was determined to find out the optimum factors which influence the surface roughness. The optimum machining conditions cutting speed $92 \mathrm{~m} / \mathrm{min}$, feed rate $0.373 \mathrm{~mm} / \mathrm{rev}$, depth of cut $0.8 \mathrm{~mm}$ and $\mathrm{Al}+5 \% \mathrm{SiC}+2.5 \% \mathrm{Gr}$ respectively.

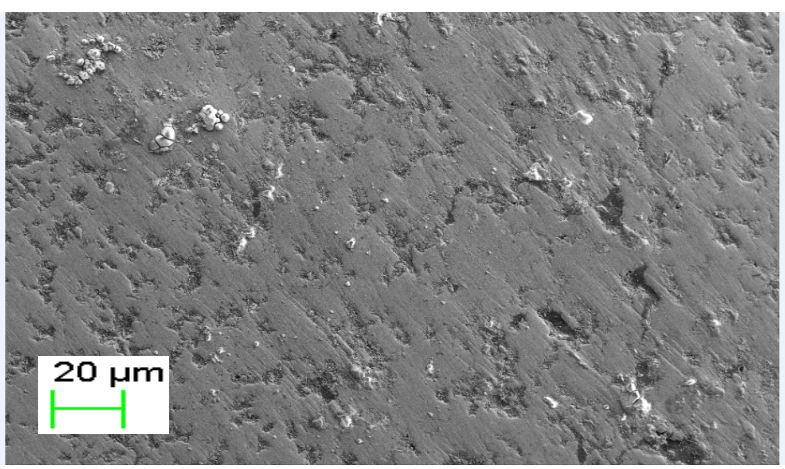

Figure 5. SEM micrograph of machined surface at optimum machining conditions $\left(A_{4} B_{2} C_{4} D_{1}\right)$

The SEM micrograph of machined surface under optimized process parameter $\left(\mathrm{A}_{4} \mathrm{~B}_{2} \mathrm{C}_{4} \mathrm{D}_{1}\right)$ is shown in Figure 5 . The surface of the machined work piece contains small surface cracks and tiny pit holes. The white particles show the transformation of aluminium during machining of $\mathrm{Al} / \mathrm{SiC} / \mathrm{Gr}$ composite.

\begin{tabular}{|l|l|l|}
\hline Element & Weight $\%$ & Atomic\% \\
\hline $\mathrm{C} \mathrm{K}$ & 27.17 & 43.05 \\
\hline $\mathrm{O} \mathrm{K}$ & 12.22 & 14.53 \\
\hline $\mathrm{Mg} \mathrm{K}$ & 0.69 & 0.54 \\
\hline $\mathrm{Al} \mathrm{K}$ & 55.95 & 39.46 \\
\hline $\mathrm{Si} \mathrm{K}$ & 2.89 & 1.96 \\
\hline $\mathrm{S} \mathrm{K}$ & 0.32 & 0.19 \\
\hline $\mathrm{Ca} \mathrm{K}$ & 0.09 & 0.04 \\
\hline $\mathrm{Fe} \mathrm{K}$ & 0.42 & 0.14 \\
\hline $\mathrm{Cu} \mathrm{K}$ & 0.24 & 0.07 \\
\hline
\end{tabular}

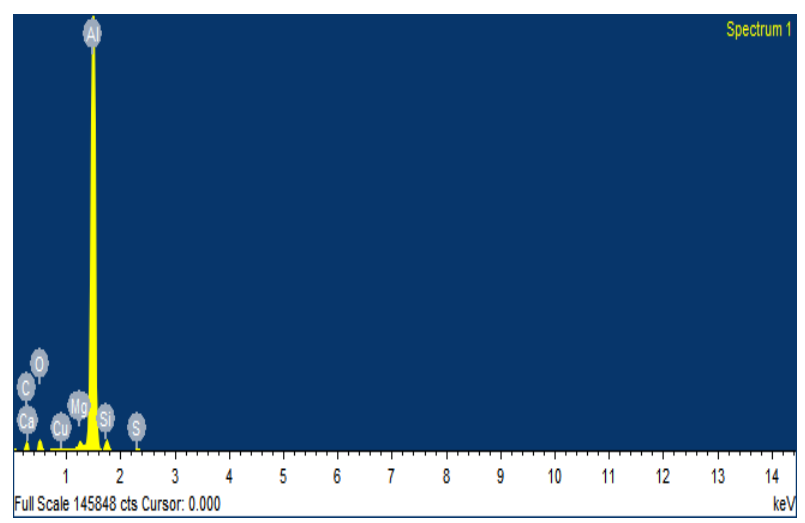

Figure 6. EDAX analysis of machined surface at optimum machining conditions $\left(A_{4} B_{2} C_{4} D_{1}\right)$

The EDAX spectra shown in Figure 6 are analysed to check the presence of elements on the machined surface of the work piece. The EDAX spectra show the presence of carbon after machining using tungsten carbide insert, which is not in the EDAX spectra before machining. EDAX results in fig 6 show the presence of Aluminium in major peak \& presence of other alloys in minor peaks. $\mathrm{Si}, \mathrm{C}, \mathrm{Mg}$ and other alloys present in Al6061 is also seen. The presence of low intensity oxygen peak was observed due to oxide formation. 


\subsection{Predicting the optimum performance}

After selecting the optimal level from main effect plots in Figure 3, prediction of $R_{a}$ value was done by Taguchi design analysis using Minitab software. A confirmation experiment is required to do the optimization, since lesser number of data are available. The confirmation experiment is used to verify the development in quality characteristics.

\subsection{Verification of optimal parameters by confirma- tion test}

After determining the optimum machining parameter levels, a new experiment was conducted. The results of the confirmation experiment are compared with the results of the orthogonal array in table 5. The result shows that the surface roughness reduces from 6.19 to $4.714 \mu \mathrm{m}$. Predicted values were close to experimental values and they are within the confidence limits.

Table 5. $R_{a}$ values for starting and optimal process parameters

\begin{tabular}{|l|l|l|l|}
\hline $\begin{array}{l}\text { Output } \\
\text { response }\end{array}$ & $\begin{array}{l}\text { Starting } \\
\text { parameters }\end{array}$ & \multicolumn{2}{|c|}{ Optimal cutting parameters } \\
\cline { 3 - 4 } Setting level & $\mathrm{A}_{1} \mathrm{~B}_{1} \mathrm{C}_{1} \mathrm{D}_{1}$ & $\mathrm{~A}_{4} \mathrm{~B}_{2} \mathrm{C}_{4} \mathrm{D}_{1}$ & $\mathrm{~A}_{4} \mathrm{~B}_{2} \mathrm{C}_{4} \mathrm{D}_{1}$ \\
\hline $\begin{array}{l}\text { Surface } \\
\text { Roughness } \\
\mathrm{R}_{\mathrm{a}}(\mu \mathrm{m})\end{array}$ & 6.19 & 5.271 & 4.714 \\
\hline S/N ratio & & & \\
\hline
\end{tabular}

The process of calculating signal to noise ratio depends on whether the quality characteristics has smaller-the-best, larger-the-better or normal-the-better.

$$
\mathrm{S} / \mathrm{N}=-10 \log _{10}\left(\mathrm{R}_{\mathrm{a}}{ }^{2}\right)
$$

where $\mathrm{Ra}$ is the average surface roughness value.

\section{RESULTS AND DISCUSSION}

The higher level of graphite addition leads to decreased vicker's hardness of $\mathrm{Al} / \mathrm{SiC} / \mathrm{Gr}$ hybrid composite. The surface roughness attained at the starting parameters and optimum condition using tungsten carbide insert are 6.19 and $4.714 \mu \mathrm{m}$ respectively, which is better than the desired surface roughness results obtained by earlier researchers. The increase in $\mathrm{Gr}$ content, tungsten carbide tool insert increases the surface roughness. Smudge and removal of softer and amorphous graphite particles on the surface of the specimen, leads to increased surface roughness values.

The multi-objective problem of getting lower surface roughness and higher material removal rate is changeed into a single-objective optimization problem using grey relational analysis. Grey relational analysis consists of three steps: Data Preprocessing, Grey relational coefficient and Grey relational grade.

Data Preprocessing is required since the range and unit in one data sequence may differ from others. Normalization is a processing step carried out to offset the effect of response units and data ranges for comparison. Equations used for data processing are:

Smaller the better

$$
\mathrm{X}_{\mathrm{i}}^{*}(\mathrm{k})=\max \mathrm{X}_{\mathrm{i}}^{\circ}(\mathrm{k})-\mathrm{X}_{\mathrm{i}}^{\circ}(\mathrm{k}) / \max \mathrm{X}_{\mathrm{i}}^{\circ}(\mathrm{k})-\min \mathrm{X}_{\mathrm{i}}^{\circ}(\mathrm{k})
$$

Higher the better

$\mathrm{X}_{\mathrm{i}}^{*}(\mathrm{k})=\mathrm{Xi}^{\circ}(\mathrm{k})-\min \mathrm{X}_{\mathrm{i}}^{\circ}(\mathrm{k}) / \max \mathrm{X}_{\mathrm{i}}^{\circ}(\mathrm{k})-\min \mathrm{X}_{\mathrm{i}}^{\circ}(\mathrm{k})(4)$

After data processing, Reference sequence or deviation sequence is calculated

$$
\Delta_{\mathrm{oi}}(\mathrm{k})=\left|\mathrm{X}_{0}^{*}(\mathrm{k})-\mathrm{X}_{\mathrm{i}}^{*}(\mathrm{k})\right|
$$

where $\Delta_{\max }=1$ and $\Delta_{\min }=0$

Calculation of grey relational coefficient

$$
\xi_{\mathrm{i}}(\mathrm{k})=\Delta_{\min }+\xi \cdot \Delta_{\max } / \Delta_{\mathrm{oi}}(\mathrm{k})+\xi \cdot \Delta_{\max }
$$

In the current study $\xi=0.5$ was considered

Calculation of grey relational grade

Grey relational grade is the average of all grey relational coefficients of the performance characteristics. Grey relational coefficients and grey relational grades are shown in table 6 .

\subsection{Grey relational Analysis}

Table 6. Grey Relational Coefficients and grey relational

\begin{tabular}{|c|c|c|c|c|c|c|}
\hline \multirow[t]{2}{*}{ Process parameters } & \multicolumn{6}{|c|}{ Grey relational grade } \\
\hline & J & $\frac{d}{d}$ & 孞 & অ & 吾 & 兰 \\
\hline $\begin{array}{l}\text { Cutting speed } \\
(\mathrm{m} / \mathrm{min})\end{array}$ & 0.495 & 0.49 & 0.497 & 0.755 & 0.265 & 1 \\
\hline Feed rate $(\mathrm{mm} / \mathrm{rev})$ & 0.6 & 0.64 & 0.5325 & 0.465 & 0.175 & 3 \\
\hline Depth of cut (mm) & 0.493 & 0.52 & 0.555 & 0.67 & 0.177 & 2 \\
\hline
\end{tabular}
grades for machining experiments

\begin{tabular}{|c|c|c|c|c|}
\hline \multirow{2}{*}{$\begin{array}{l}\text { EXP } \\
\text { NO. }\end{array}$} & \multicolumn{2}{l|}{$\begin{array}{l}\text { Grey Relational } \\
\text { coefficients }\end{array}$} & $\begin{array}{l}\text { Grey } \\
\text { Relational } \\
\text { Grade }\end{array}$ & \\
\cline { 2 - 5 } & $\mathbf{R}_{\mathbf{a}}(\boldsymbol{\mu \mathbf { m }})$ & $\begin{array}{l}\text { MRR } \\
(\mathbf{g} / \mathbf{m i n})\end{array}$ & & \\
\hline 1 & 1.00 & 0.33 & 0.67 & 5 \\
\hline 2 & 0.48 & 0.37 & 0.42 & 13 \\
\hline 3 & 0.40 & 0.42 & 0.41 & 14 \\
\hline 4 & 0.45 & 0.52 & 0.48 & 7 \\
\hline 5 & 0.53 & 0.37 & 0.45 & 12 \\
\hline 6 & 0.56 & 0.35 & 0.46 & 10 \\
\hline 7 & 0.53 & 0.63 & 0.58 & 6 \\
\hline 8 & 0.35 & 0.58 & 0.47 & 8 \\
\hline 9 & 0.34 & 0.46 & 0.40 & 15 \\
\hline 10 & 0.69 & 0.79 & 0.74 & 4 \\
\hline 11 & 0.39 & 0.39 & 0.39 & 16 \\
\hline 12 & 0.33 & 0.58 & 0.46 & 9 \\
\hline 13 & 0.90 & 0.85 & 0.88 & 2 \\
\hline 14 & 0.88 & 1.00 & 0.94 & 1 \\
\hline 15 & 0.76 & 0.74 & 0.75 & 3 \\
\hline 16 & 0.41 & 0.48 & 0.45 & 11 \\
\hline
\end{tabular}

Table 7. Response table for grey relational grade

Means of grey relational grade for each level of process parameters are obtained and results are shown in table 7.

\section{CONCLUSIONS}

In this research work, the effect of graphite addition to $\mathrm{Al} / \mathrm{SiC}$ hybrid metal matrix composite is studied with surface roughness as the desired response, while 
machining using tungsten carbide insert. The addition of graphite in $\mathrm{Al} / \mathrm{SiC} / \mathrm{Gr}$ composite increases the surface roughness, when machining with tungsten carbide insert. $\mathrm{Al} / \mathrm{SiC} / \mathrm{Gr}$ composite produced discontinuous elemental chips, which leads to easier machining, due to the lubricant property of graphite particles. The higher percentage of graphite results in decreased hardness of $\mathrm{Al} / \mathrm{SiC} / \mathrm{Gr}$ hybrid composite. The Vicker's hardness values of aluminium hybrid composites with $5 \% \mathrm{SiC}$ and $2.5 \% \mathrm{Gr}, 5 \% \mathrm{Gr}, 7.5 \% \mathrm{Gr}$ are 83,72 and $54 \mathrm{VHN}$ respectively. The major influencing factors based on Analysis of Variance towards surface roughness is feed rate(35.83\%) and, cutting speed(30.01\%) while depth of $\operatorname{cut}(14.3 \%)$ has minor effect on surface roughness. The surface roughness obtained at the starting parameters and optimum condition using tungsten carbide insert are 6.19 and $4.714 \mu \mathrm{m}$ respectively. Grey relational analysis was done for the surface roughness and MRR performance characteristics. The surface finish is better when feed rate and reinforcement of $\mathrm{Gr}$ is at $2.5 \%$ level. Further research in this area can be carried out by developing a fuzzy based model, by incorporating the expert knowledge. This model will reduce the cost and time for surface roughness prediction.

\section{REFERENCES}

[1] Tameer, O., Erol, K., Orhan C.: Investigation of mechanical and machinability properties of $\mathrm{SiC}$ particle reinforced Al-MMC, Journal of Materials Processing Technology,2008, 198, pp.220-225.

[2] Harish, K.G., Ketan, V., Alakesh, M., Rajesh, K.: Hybrid Metal Matrix Composites and firther improvement in their machinability - A Review, International Journal of Latest Research in Science and Technology 2012, Vol.I, Issue 1 :pp.36-44.

[3] Lazarevic, D., Jankovic, P., Madic, M., Lazarevic, A.: Robust Conditions for Cutting Force Minimization in Polyamide Turning Process, FME Transactions Vol 43, pp. 114-118, 2015.

[4] Hull, D., Clyne, T.W.: An Introduction to composite Materials, Cambridge University Press, 2014.

[5] Boothroyd, G., Winston A.K.: Fundamentals of Machining and Machine Tools, CRC Taylor \& Francis, 2011.

[6] Sahoo, A.K., Swastik, P.: Modeling and optimization of $\mathrm{Al} / \mathrm{SiCp} \mathrm{MMC}$ machining using Taguchi approach, Measurement 2013, Vol. 46,pp. 3064-3072.

[7] Sanjay, K.M.: Composites Manufacturing Materials, Product and Process Engineering, CRC press LLC, 2002.

[8] Suresh, P., Marimuthu, K., Ranganathan, S., Rajmohan, T.:Optimization of machining parameters in turning of Al-Sic-Gr hybrid metal matrix composites using grey-fuzzy algorithm, Transactions of Nonferrous Metals Society of China, 2014,pp 2805 -2814.

[9] Muthukrishnan, N., Davim, J.P.: Optimization of machining parameters of $\mathrm{Al} / \mathrm{SiC}-\mathrm{MMC}$ with
ANOVA and ANN analysis, Journal of Materials Processing technology,2009, 209,pp. 225-232.

[10] Basavarajappa, S., Davim, J.P.: Influence of Graphite Particles on Surface Roughness and Chip Formation Studies in Turning Metal matrix Composites, Materials Research, 2013,pp. 990996.

[11] Suhasini, G., Mamidala, R. and William, P.: Machining of MMCs : A Review, Machining Science and technology, 2013, Vol.17, Issue 1, pp.41-73.

[12] Xianhua, T., Jun, Z., Wenzhen, Q., Feng, G., Yintaowang and Helin, P.: Performance of Ceramic tools in high speed cutting iron-based super alloys, Machining Science and Technology, 2017 Vol 21, Issue 2, pp.279-290.

[13] Toth-Laufer, E., Horvarth, R.: Fuzzy Model based Surface Roughness prediction of Fine Turning, FME Transactions vol 45, pp. 181-188, 2017.

[14] Abdullah, O.I., Schlattmann, J., Lytkin, M.: Effect of Surface Roughness on the Thermoelastic Behaviour of Friction Clutches, FME Transactions Vol 43, pp. 241-248, 2015.

[15] Marichamy, S., Ravichandran, M., Stalin, B., Sridhar, B.: Optimization of Abrasive water jet machining parameters for $\alpha-\beta$ brass using Taguchi Methodology, FME Transactions, 2019,Vol. 47, pp 116-121.

[16] Dhawan V., Debnath K., Inderdeep S., Sehijpal S.: Prediction of Forces during Drilling of Composite Laminates Using Artificial Neural Network : A New Approach, FME Transactions, 2016, Vol. 44, pp 36-42.

[17] Sivaiah, P., and Chakradhar, D.: Multi performance characteristics optimization in cryogenic turning of 17-4 PH stainless steel using Taguchi coupled grey relational analysis, Advances in Materials and Processing Technologies, Vol 3, pp.431-447, 2018.

[18] Montgomery, D.C.: Design and analysis of experiments, John Wiley \& Sons, 2014.

\section{ОПТИМИЗАЦИЈА ПАРАМЕТАРА ОБРАДЕ КОД ХИБРИДНОГ КОМПОЗИТА ОЈАЧАНОГ Al/SiC/Gr ПРИМЕНОМ АНАЛИЗЕ ANOVA И ГРЕЈ РЕЛАЦИОНЕ АНАЛИЗЕ}

\section{М. Еланго, К. Анамалаи}

Изучава се утицај додавања графита композиту ојачаном $\mathrm{Al} / \mathrm{SiC}$ који је добијен мешањем уливањем. Припремљена су три узорка од легуре Al6061 + 5 теж.проц. $\mathrm{SiC}$ и променљивим процентом графита. Наведена легура је погодна за обраду и заваривање и најчешће се користи за израду крила и трупа летелица. Захтеви које поставља обрада композита су толеранција димензија, храпавост површине и израда рупа. Слојевити композит ојачан $\mathrm{Al} / \mathrm{SiC} / \mathrm{Gr}$ ce користи код коморе за сагоревање гасне турбине. Обрада хибридног композита је обављена на 
токарском уређају Esteem ETM 356 помоћу волфрамског карбидног уметка. Оптимизација три параметра обраде: брзина резања, брзина помоћног кретања и дубина резања обављена је на четири нивоа. На основу резултата добијених ANOVA анализом брзине помоћног кретања (35,83\%) утврђено је да има значајног утицаја на површинску храпавост. Греј релациона анализа је примењена за истовремено побољшање уклањања материјала и храпавости. 